\title{
Beanie Babies: An Idea Whose Time Has Come - Or - A Craze Whose Time Has Almost Run?
}

J. G. Gallagher, (Email: J.Gallagher@ napier.ac.uk), Napier University, Scotland

\begin{abstract}
TY Warner's objectives are the same as the company. It is a fad product which is usually adapted fast, peaks early and declines quickly, but Ty Warner kept reinventing the product. (Kotler)
\end{abstract}

\section{INTRODUCTION}

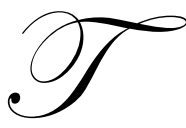

y Incorporated was founded 1986 and rose to become the most successful and profitable company in the history of the U.S. toy industry with over $\$ 1$ Billion in sales. In the stuffed animal trade called the "plush" trade by the toy industry, H. Ty Warner, created "Beanie Babies" designed to be a safe, non-violent, inexpensive, toy that children could afford to buy with their allowance. These under-stuffed (which allowed them to be posed), gender neutral, velvet animals with tiny PVC pellets in the paws were small enough to fit into a child's hand. It was a concept that Ty Warner exploited with single-minded pursuance to make Beanie Baby into a global product.

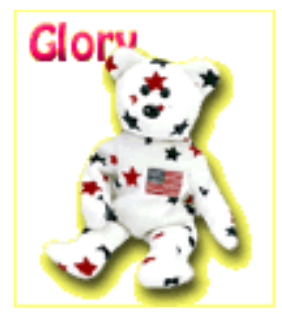

The product had wide appeal. Not only was it a toy, but it is also became a collectors item for all ages and genders.

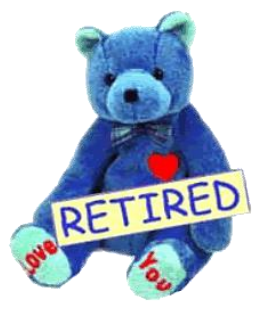

Ty Warner, the inventor of Beanie Babies, did not immediately hit upon the Beanie Baby concept rather his embryonic experimentation into Plush Toys came in 1986,

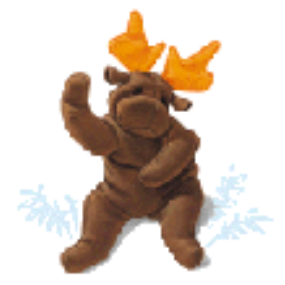

Chocolate

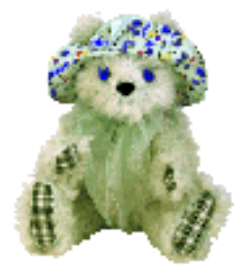

through the creation of the "Himalayan Cats" which began with Smokey, Angel, Peaches, and Ginger which sold for \$20 each. Although Ty Inc., at that time, was mildly successful it was not until 1993 when the original nine beanies (a dog, a lobster, a frog, a moose, a platypus, a bear, a pig, a whale, and a dolphin) emerged that the company began to take off. This growth, however, became meteoric after the first eleven beanies retired in 1996. Their popularity migrated from Chicago to the rest of America and then into Europe, initially through the UK and Germany and then into the Far East. 
The company's product range rapidly developed to include:

Beanie Babies(R),

Teenie Beanie Boppers(R),

Beanie Boppers(R),

Punkies(R),

Pluffies(R),

Ty Classic(R),

Beanie Buddies(R) and

Baby $\operatorname{Ty}(\mathrm{R})$.

The red Ty Heart Logo(R)

, is recognized around the world and can be found on all Ty products.

In December 1998 Warner took a full-page advertisement in the Wall Street Journal to proclaim his company the biggest toy manufacturer in America. This was greeted with some scepticism in the industry. Stung and surprised, he duly ordered his accountants to release just enough information to show that it was true. Ty's Beanie Baby Empire was bigger than the conventional toy giants Hasbro and Mattel combined.

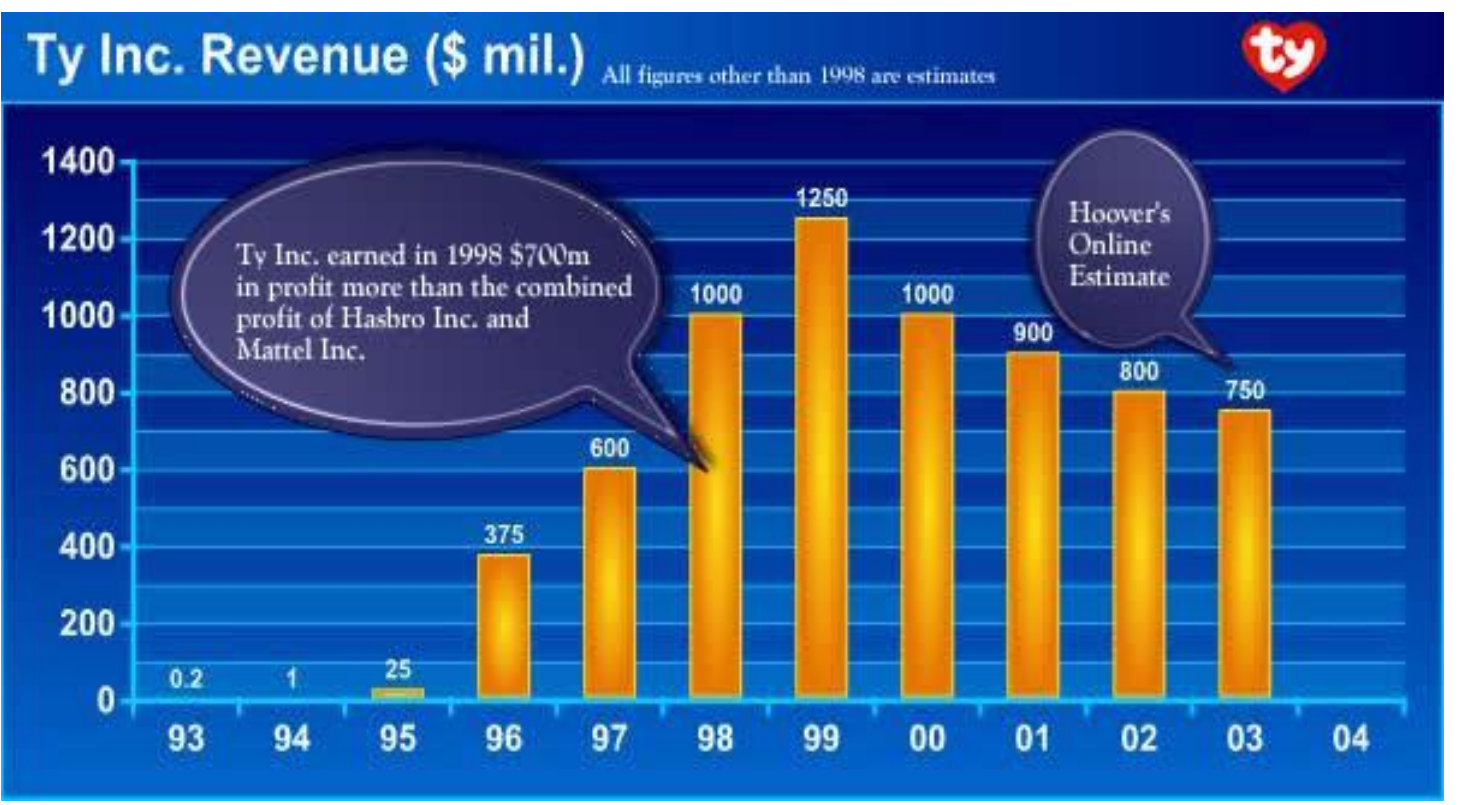




\section{H. TY WARNER (FOUNDER, DESIGNER, AND CEO)}

Warner is intensely private rarely granting interviews.(1) His company does not disclose sales or production figures, displays no logo or identifying sign on its glass-walled headquarters, and keeps its phone number unlisted.

Named after the first man inducted into the Baseball Hall of Fame (2), H. Ty Warner, the creator of Beanies was born in Chicago, Illinois on the $3^{\text {rd }}$ of September 1944. Living in Chicago for some time the Warner family finally moved to La Grange, a pleasant and unspoilt Victorian village about half an hour west of Chicago in 1948.

Like most of Warner's history a veil of uncertainty clouds the facts. It is reported that his father was either a jewellery salesman or an employee for Jewel Stores, a local supermarket chain. In either case he was highly successful at what he did. He could afford a large house and the cost of education for his children.

- $\quad$ From Kindergarten to the age of 13, Warner went to Cossit School,

- $\quad$ At 14, he moved to Lyons High School in Chicago,

- $\quad$ After just three terms at Lyons, Warner was packed off to St John's Military Academy, a boy's private boarding school in Wisconsin (the school does not provide any information on him).

- $\quad$ Warner then attended Kalamazoo College (studied drama but dropped out after one year).

Warner, whilst studying drama at college, decided to leave and try his luck in Hollywood as an actor. This, however, did not work out and he took work as a petrol pump attendant and sold cameras door to door.

It was at this time (1962) that Warner joined Dakin Inc.(3), a large toy company based in San Francisco manufacturing plush, stuffed-animals, in particular teddy bears, as a salesman.

Warner's marketing skills were honed at Dakin. While working the shops of his native Illinois, he seems to have discovered his vocation and undergone something of a personality change - he purchased a white Rolls Royce convertible, arriving for sales appointments with retailers dressed very eccentrically in a knee-length fur coat and a top hat while carrying a cane. A gimmick he once said was calculated to make people curious about what he was selling.

It was all to get in to see the buyer,' he told People Magazine. 'I figured if I was eccentric-looking in Indiana, people would think, "What is he selling? Let's look in his case.

After 18 years Warner left Dakin in 1980 apparently suffering from burn-out.

Warner moved to Italy, near Sorrento, where he had friends. He stayed there until 1983.

It's the opposite of what we do here,' he later noted. 'Everyone knows each other. They have a three-hour lunch, swim, lay in the sun. It's a very enjoyable lifestyle.

In Italy he became particularly taken with a range of cuddly plush cats and wondered why nothing like them existed back home. These 'Himalayan Cats' became the basis of his first products when he returned to America. He combined his savings ( $\$ 100,000$ salary from Dakin) with a mortgage on a small flat he owned in Hinsdale, another suburb not far from where he grew up and $\$ 50,000$ he inherited after the death of this father to set out on the road to founding Ty Inc. in 1983, incorporated in 1986.

He hired two workers, Miss Nickels (spokeswoman) and Patricia Roche, who now heads the UK operation. However, from the start, employees of Ty Inc. have to pledge never to talk about the company or their boss in public. Those who do are fired. Even some of Warner's closest business associates communicate with him 
only in writing. Nevertheless, Warner reportedly treats his employees well, one year giving bonuses equal to their yearly salary as well as making limited collectible babies for them.

Warner's genius was to leave out some of the stuffing in his toys, to make the animals less stiff and more lifelike and easily posed. His first line of toys introduced -4 inexpensive, underplushed Himalayan cats. Altogether, there were 10 cats each cat was basically the same with the differences being colours, names, and sizes.

Soon the Himalayan Cats were selling out in local shops.

Often sneered at and jokingly called 'road kill' Warner nevertheless, sold 30,000 at the Atlanta toy fair. By 1992 the Ty catalogue had grown to dozens of animals. But Warner was looking for something else, an appealing toy that children could buy with pocket money, something collectable and costing less than $\$ 5.00$.

The 'original nine' Beanie Babies hit the shops of Chicago in 1994 after they had been introduced to the world in late 1993 at the World Toy Fair in New York City. The ‘Beanie Phenomenon' had started.

Warner has never married, nor does he have any children of his own, although he clearly loves children. In the 'People' interview reference was made to a long-term relationship with Faith McGowan, a local lighting designer with two teenage daughters. She lives in a nearby house to Warner - her address is listed only as a PO Box.

Nowadays, Warner is intensely private. He doesn't give interviews. His company does not disclose sales or production figures, displays no logo or identifying sign on its glass-walled headquarters, and keeps its phone number unlisted.

\section{PERSONAL WEALTH / ASSETS}

Warner is often called a recluse. He hid his wealth so well that the Forbes magazine admitted that it failed to spot him for its 1998 list of wealthiest men in America.

- $\quad$ Previous listing of personal wealth - between $\$ 5$ billion and 7 billion - between $26^{\text {th }}$ (Forbes Magazine) and 37th richest man in USA.

- $\quad$ Home is a $\$ 715,000$ white contemporary house in Oakbrook, Illinois

- $\quad$ Purchased a reputedly $\$ 8$ million, 8,000 sq ft Mediterranean-style home with ocean views near Santa Barbara in July 2000.

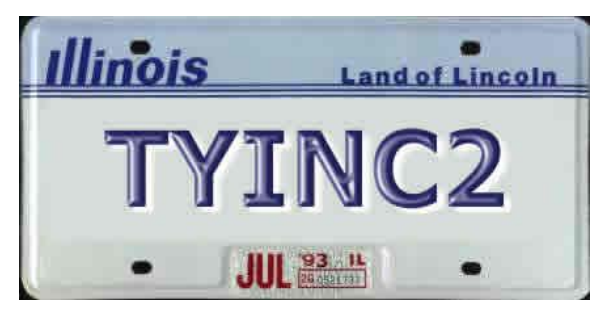

One of Warner's loves is luxury cars. He either drives to work in a 1993 Mercedes 600 SL [license plate: TYINC2], or else in a 1998 Ferrari. There is no place reserved for Warner in the headquarters' parking lots. He also loves to play tennis, eat Italian cuisine, and enjoys listening to Mick Jagger. He is also an accomplished classical pianist, taught by his mother. 
Warner is known for his generosity. During the last five years his donations are estimated to be in excess of $\$ 75$ million. The most recent donations include:

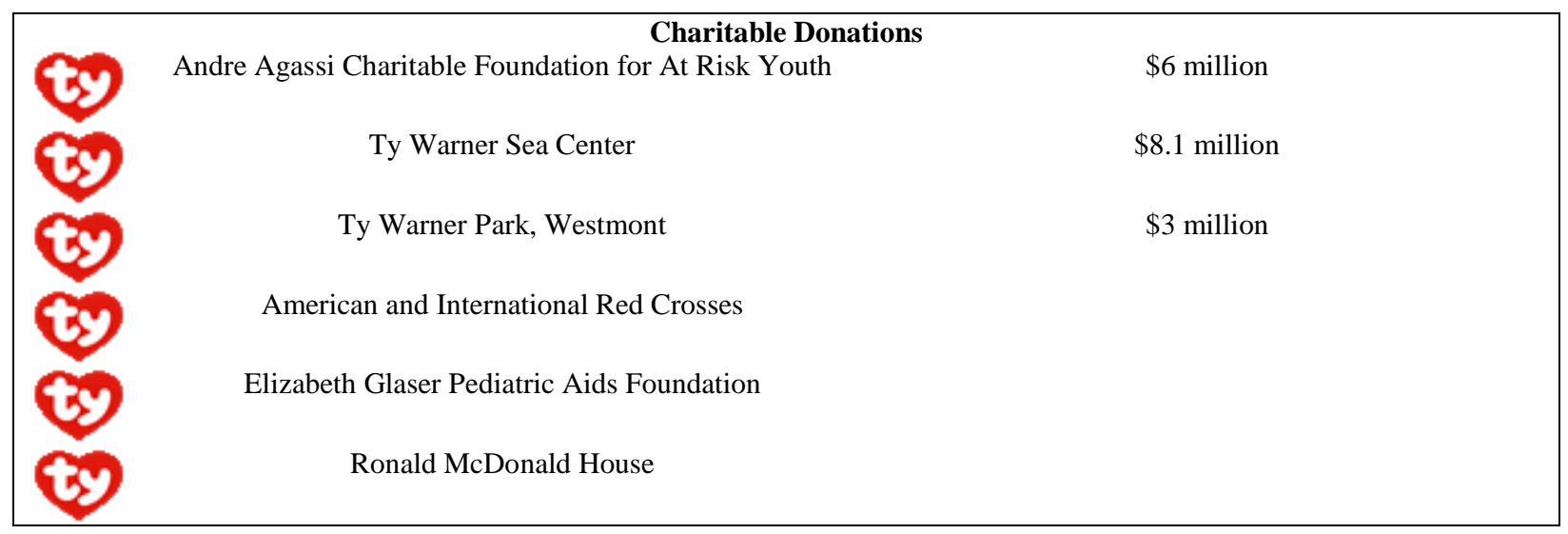

in addition he has created Beanie Babies for the sole purpose of generating money for a charity for example: Courage the dog, in honour of 9/11 rescuers or "Ronnie" bear where the proceeds go to upgrade living quarters of crew members serving aboard the US Navy's newest aircraft carrier, the U.S.S. Ronald Reagan.

However, he has also acquired a reputation for extreme ruthlessness. His team of lawyers uncompromisingly hunts down any perceived infringements of copyright.

One beanie Warner created for charity was Beanie Baby Issy. However, there are currently 63 different Issy bears! Each of these has a different city printed on their hang and 'tush' tag representing a location of a Four Seasons Hotel.

\section{TY INC.}

Ty Inc. is a privately owned company (100\% owned by H. Ty Warner) which has one of its headquarters base in a suburb 20 miles west of Chicago in an unidentified glass and concrete building with no identification of what is inside.

Another headquarters is based in Oakbank and is equally discreet. The Company's official mailing address is a PO Box address and its telephone number is unlisted.

With its headquarters in the USA Ty Inc. has also divisions abroad namely:

- Ty Canada,

- $\quad$ Ty Europe (Germany and UK merged),

- Ty Japan 


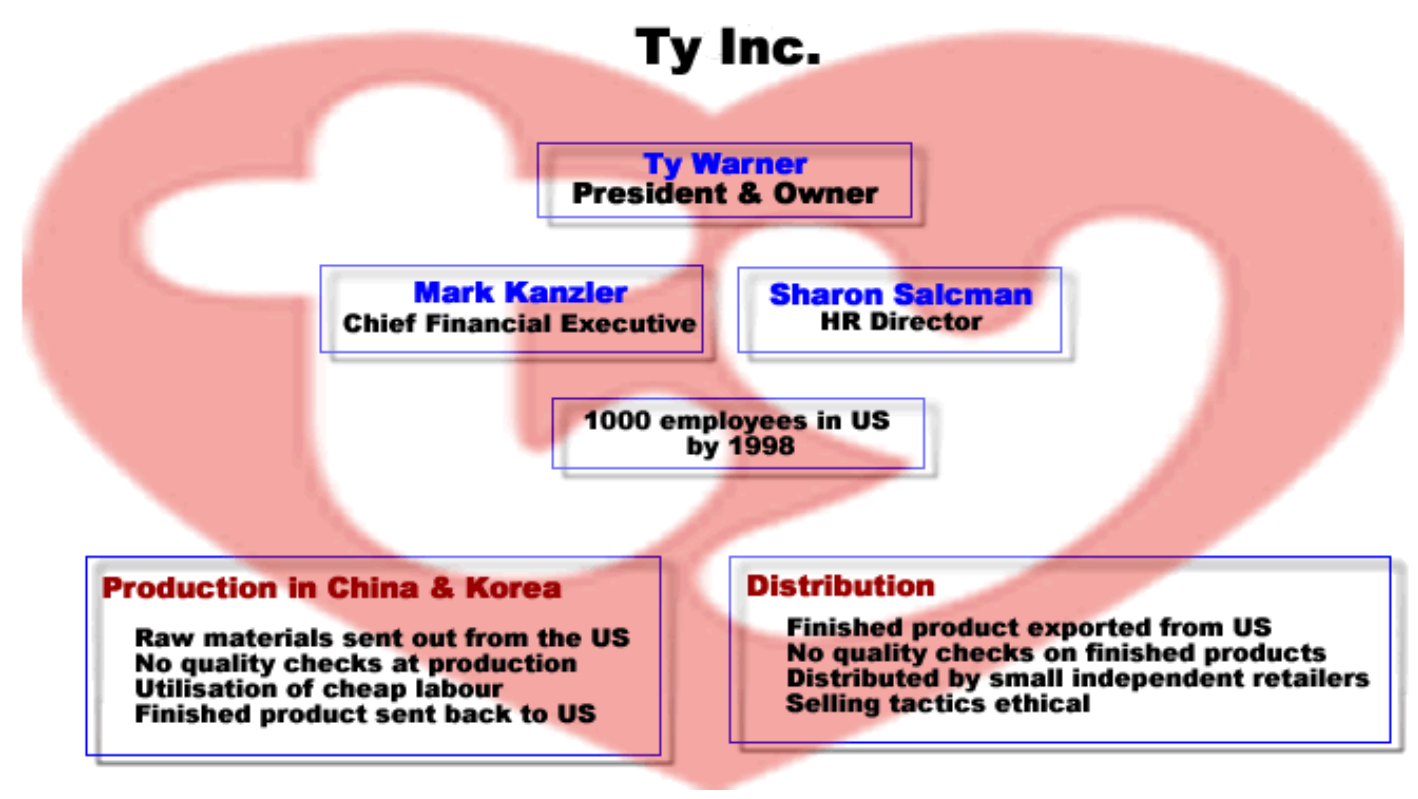

\section{THE INDUSTRY}

The toy industry is one of the world's oldest industries. It is an industry which is mature with high concentration levels, highly competitive and global in nature. Today, approximately $75 \%$ of production is located in China. The industry is characterised by:

- Short product life cycle

- $\quad$ Seasonal demand.

- Constant product innovation

- $\quad$ Time to market

- $\quad$ High product turnover

Very few toy products have what it takes to last longer than one or two years, with this dilemma major toy makers are continually seeking to manage demand. Warner achieves demand management through a rolling mix strategy "This strategy developed an organised, non-reactionary method of new product introduction and old product obsolescence." The launch of new Beanies Babies, limited editions and the retiring of older styles.... "created urgency among consumers to buy the products while they were available." This approach boosts sales and provides supply chain dividends through the elimination of forecasting the performance of any particular style. Ty Warner Beanie Babies' strategy is to empty shelves - the deliberate creation of scarcity, drives demand up.

Product introduction is based on identified target segments, initially Chicago then US children, now global market children and adults have the Beanie Babies bug.

Beanie Babies initially targeted at kids for purchase with their own allowance money. Adults however saw Beanie Babies as an investment, they fixated on the toys tendency to rise in value. Variety of products ranging from products aimed at markets with high levels of disposable income to low cost products.

Promotion through McDonalds, a global player, had created global awareness and demand without the expense of advertising. 
Internet - website allowed access to much larger market, again global. Internet sales, e-commerce, creation of web site, fan club, newsletters etc. spurs demand, and repeat business.

Toy Fads - Short life cycles
- Trolls
- $\quad$ Pokemon monsters
- $\quad$ Cabbage Patch Kids
- Tamagotchi cyber pets
- $\quad$ Furbies

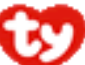

\section{PRODUCTION}

Warner's philosophy has always been to create products of unique design, products of the highest quality, and to price these products so they can be easily affordable to children. This philosophy has never changed.

His great insight was that he recognised that the world needed an attractive plush toy that a child could afford. He designed it himself and brought it to market in 1994.

Kids identify with names. In the beginning, I thought of the cute names. Now I take them into the office and everyone makes suggestions. Ty Warner in from Korea.

After the Atlanta Toy Fair Warner rented a 12,000 sq. ft. warehouse in Lombard, Illinois and shipped goods

However, in 1991 - 92 Warner designed a toy, called the Collectable Bears Series - limited bear series which had individually numbered stripes sewn into their right foot which was added to the Ty Catalogue

By 1992 the Ty Catalogue had several different plush toys including dogs, monkeys, bears, farm animals with prices ranging from $\$ 5, \$ 10$ and $\$ 20$.

Early 1993, Ty introduced, for a couple of months, Brownie the Bear and Punchers the Lobster as the first two official 'Beanie Babies'.

However, at the New York Fair Ty unveiled a new line of nine Beanie Babies which launched in early 1994 in the shops:

The 'Original Nine'

\begin{tabular}{cccc} 
& The 'Original Nine' & Retired \\
\hline 1 & Spot & the dog, (without spot) & Oct 1997 \\
2 & Squealer & the pig, & May 1998 \\
3 & Patti & the platypus, & May 1998 \\
4 & Cubbie & the bear, (replaced Brownie) & Jan 1998 \\
5 & Chocolate & the moose, & Dec 1998 \\
6 & Pinchers & the lobster, (replaced & May 1998 \\
& & Punchers) & May 1997 \\
7 & Splash & the killer whale, & Oct 1997 \\
9 & Legs & the frog and & May 1997
\end{tabular}


New styles were added every six months or so. Beanies that did not sell were taken out of production, or "retired" quietly whilst others whose initial stock-run had sold out were likewise retired. However, the real boom in trade did not materialise until late 1996. This came after Ty announced the first 11 'retirals' in middle 1995. They became an instant hit. Thus older designs became instantly sought-after, while newer designs became 'must-haves' for collectors, adult and children alike.

Starting with January 1st, Ty decided to have annual retirement dates where beanies would be discontinued with a great celebration. Each time the newest retirees would be announced in a different way. There are currently about 3-4 retirements every year.

Not only did Warner keep introducing new Beanie characters, but he also made changes in a line when he wasn't satisfied with the style or colour. Thus, an orange Digger the Crab gave way to a richer-red Digger after a year. Suddenly, collectors were swooping on the scarcer original version, eventually bidding it up to $\$ 600$ or more on the resale market - perhaps five times what a red Digger might bring.

It was not a great step for Warner to take to discover that he could create the same effect by abruptly ceasing production of a design. Without warning, he would announce such "retirements" on the Ty Inc. Web site (launched in 1996 WWW.Ty.com), sending collectors scrambling all over again.

By accident or design, these actions all helped foster an aura of scarcity around the Beanies, even as Ty Inc. factories in China were pumping them out by the hundreds of millions.

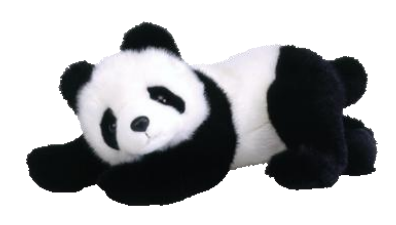

Xiolin

Ty produces through independent factories in China and Korea, generating long transit times and information lags between manufacturing and target markets.

Beanie Babies are manufactured in China, Korea and Indonesia. China has over 100 factories and currently manufactures the greatest proportion of products. Beanies made in China are delivered to the USA and Canada and very little to the UK. Beanies created in Korea are sent solely to the UK.

Indonesian beanies were delivered to the UK and in small amounts to Canada, However, due to quality issues, the Indonesian production has stopped.

Control of product design and materials were pre-eminent but quality control was not part of the production process in China and Korea. Errors were allowed to occur which helped increase value, e.g. beanies that went out with ear tag and 'tush' tag the wrong way round.

Warner's strategy was simple, he aimed for quality based on value engineering. The product was simple with few details. Each beanie had limited colours of fabric with few facial details. They were hand-sewn in Asia and came with antic names such as Freckles the Leopard, Tank the Armadillo and Pinchers the Lobster. 
Each new beanie had a hang tag which consisted of a single double-sided Ty tag $\mathbb{G}$ with a smaller Ty on the front and the animal's name and style number on the back. Newer generation hang tags are locket style tags

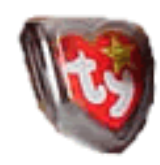

containing poems(4) and date of birth inside. In addition, they also had a white sewn-in 'tush' tag with black lettering. This was a response to counterfeit Beanies which were appearing all over the world. Ty introduce holograms on the tush tags of all Beanies using a special ink.

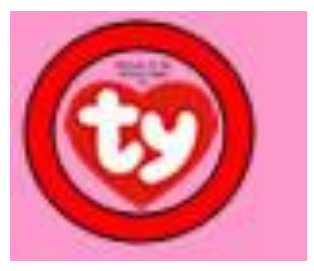

Warner adopted the distribution model for higher-end plush toys, selling Beanie Babies through specialty gift and toy shops rather than through Wal-Mart, Toys "R" Us or other giant chain stores (5). That way, buyers couldn't find the entire line in one place, and further, would seldom encounter piles of unsold Beanies. The result was the enhancing of their status as collectibles, not mere commodities(6).

A massive second-hand Beanie market sprang up, mostly on the Internet. Prices for the rarer designs have spiralled. The 'Billionaire Bear', created by Warner as a limited-edition 'thank you' for his workers to commemorate \$1-billion sales of 1998 , is now worth more than $\$ 2,000$.

\section{MARKETING}

Initially Beanie Babies became popular because children could afford their prices - $\$ 4$ to $\$ 5$. Later they became valuable collectables to adults who could sell a single toy for as much as $\$ 1000$.

Warner, has never actually advertised his Beanie Babies and never sold them in major chain stores such as Toys 'R' Us. Instead, ever since the Beanies first appearance, he has sold his toys only through small gift shops, grateful for all the business he can throw at their way. In this manner he can call all the shots.

Ty restricted beanie supply to a maximum of 36 per style thereby, making supplies very limited. Additionally, by limiting sales to niche retailers and curbing the number of these suppliers it created pockets of scarcity which kept buyers baited.

In 1995, Ty decided to sporadically announce retirements of certain Beanie Baby styles, and then introduce new styles to continuously keep the collectible line fresh.

Warner defends his brand zealously, bringing scores of lawsuits against what he sees as counterfeits or other trademark infringements. "Our philosophy was we never took any prisoners," said James P. White, a partner in a Chicago law firm that has represented Ty Inc. 


\section{TY INC. PRICING PHILOSOPHY}

Ty do not publish a suggested selling price, rather they rely on their retailers to remain true to the Ty pricing policy. Although Ty cannot control the secondary market, they do however decide who is a Ty customer. To this end, they will discontinue the sale of their products to accounts that knowingly sell to secondary market dealers, divert product, or sell on consignment. By not selling to the end consumer, the account becomes a distributor and Ty's Company policy clearly states that they do not sell to distributors.

Furthermore, the company stated that:

Situations we currently observe in the market place compel us to inform consumers of our position. Beanie Babies ® plush styles are designed for children to collect and are priced to sell for about \$5.00. This includes all current styles and new, as well as new product introductions such as Princess and Erin. In addition, we expect retailers to place all Ty products out on the shelf so that each consumer has the opportunity to purchase every style that we produce and each style that we want.

When Ty determines that its pricing is not being followed, they cease to supply that retailer.

As the beanie craze spread, Ty created the company's website (www.Ty.com). The site included:

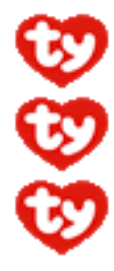

a list

a guestbook

the latest beanie news (with pictures) of all the beanies ever made,

where collectors from all over could contact one another,

With over a billion visits in its first few years it is probably one of the most popular sites on the net.

In 1998, Ty Inc joined with Cyrk Inc, a Gloucester, Massachusetts corporate promotion company, to create the Beanie Official Club (BBOC). The company created a BBOC gold kit which included an offer to purchase an exclusive club bear named Clubby when a customer joined.

The BBOC facilitated the growth of other beanie web sites to the extent that upwards of 17,000 sites were dedicated to beanies in the first few years after BBOC was set up. These sites were mainly in existence for the trading in second hand beanies (7).

In 1999, Ty invested $\$ 10$ million in Cyrk Inc. for a 7.3 percent stake in the company. The company then produced the first Ty Series I BBOC Trading Cards, which featured the different Beanie Babies on them. This was followed by a BBOC Platinum kit, which included a club bear, Clubby II, inside the carrying case. Other products produced by Cyrk Inc., were tag protectors, cubes, calendars, trading card binders, trading card sleeves, trading card storage cases, and more.

The last assignment by Cyrk was to distributed Clubby Beanie Buddies via the BBOC website. However, Cyrk was forced to pay $\$ 216,000$ as a civil penalty for failing to promptly deliver the toys in the time set by its advertisements, which is illegal by the Federal Trade Commission. Ty has reportedly now fired Cyrk Inc., due to the mess that was brought with the Clubby Beanie Buddy promotion. 


\section{MCDONALDS \& TY S}

McDonald's launched, as part of its celebration of 25 Years of Happy Meals, a classic collection of Ty Teenie Beanie Babies. These McDonald's Teenies go back to 1993 when ten Ty Teenie Beanies were made as part of a promotion with the McDonald's Burger Chain.

These 12 new McDonald's Teenies would, this time, be dressed up as McDonald's characters past and present and one would be included in each special birthday Happy Meal(8).

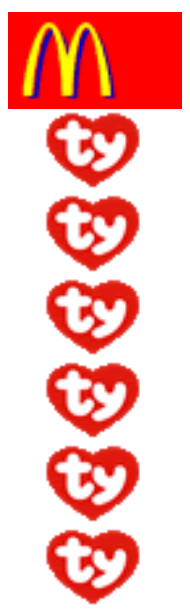

McDona
Happy Meal 25th Bear
Birdie(R) the Bear
McNuggets(R) the Bear
Happy Meal(R) the Bear
Hamburger(R) the Bear
Fries the Bear

McDonald's/Ty Inc.

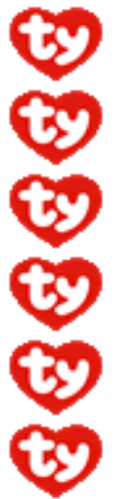

\author{
(x) \\ Burger the Bear \\ Golden Arches the Bear \\ Ronald McDonald(R) the \\ Bear \\ Shake the Bear \\ Big Red Shoe the Bear \\ Grimace(R) the Bear
}

In addition, Happy Meal packaging would reflect the excitement of the celebration, with anniversarythemed boxes, Hamburger and Cheeseburger wraps, Chicken McNuggets box and beverage cup.

\section{FINANCE}

In 1998 Warner's Westmont-based Ty Inc. earned \$700 million in profits, the only time the secretive Warner publicly disclosed financial figures for his privately held company. And even then he did so only to prove that he indeed was the largest toy maker, trumping the then-combined $\$ 538$ million in profits earned by his publicly held rivals, Hasbro Inc. and Mattel Inc.

- $\quad$ No. 391 on Largest Private Cos. 2001,

- $\quad$ No. 185 on Largest Private Cos. 2000,

- $\quad$ No. 133 on Largest Private Cos. 1999

However, in August 1999, Ty shocked the collecting world by announcing on the internet, that it would stop making Beanie Babies on Dec. 31, $1999-11.59 \mathrm{pm}$, this at a time when the rate of sales growth had started to decline. Panic buying then ensued. 


\section{Beanie Babies}

Growth

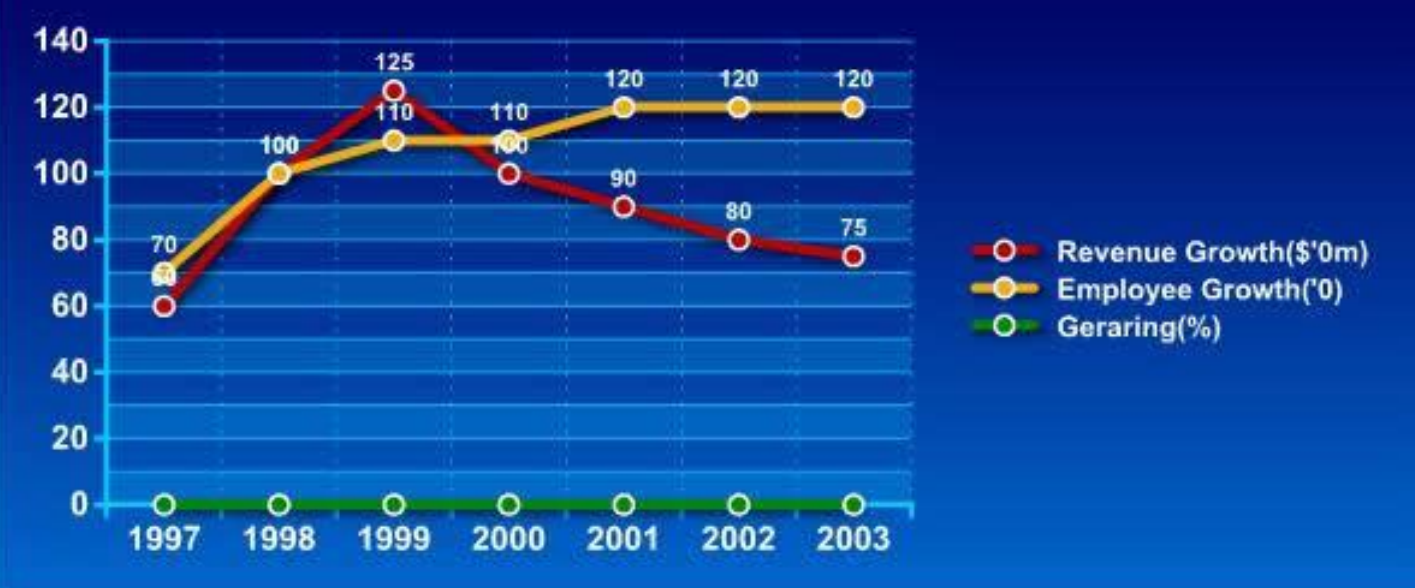

The company never publicly explained its reasons, but Beanies auction prices had begun to stagnate, so sceptical collectors saw the move as a desperate effort to stoke the fervour.

Many toy analysts believed Warner planned to continue Beanies in some form. He had expanded his factories and had several trademark applications pending for such names as E Babies, Bean E Buddy and Bean E Baby.

Warner commented that:

After much thought, I am willing to put the fate of Beanie Babies in your hands... You make the decision. You have inspired the Beanie Babies line through your devotion to them. Ty

He announced that at 6am Dec 31 1999, Beanie Baby collectors could cast ballots on the official Ty Web site for 50 cents (the entire proceeds going to Elizabeth Glaser Pediatric AIDS Foundation) on whether beanies should be discontinued or not.

The result of the ballot was not unexpected and Ty announced it would resume production in early 2000 . Today, a rare Beanie - perhaps with a Ty Warner autograph - may still fetch more than $\$ 1,000$ at auction. The toy is still a good seller at retail, but people no longer line up to buy them.

\section{FUTURE}

With his newfound fortune, Warner has branched out into other areas in particular, the purchase of high quality properties such as: 


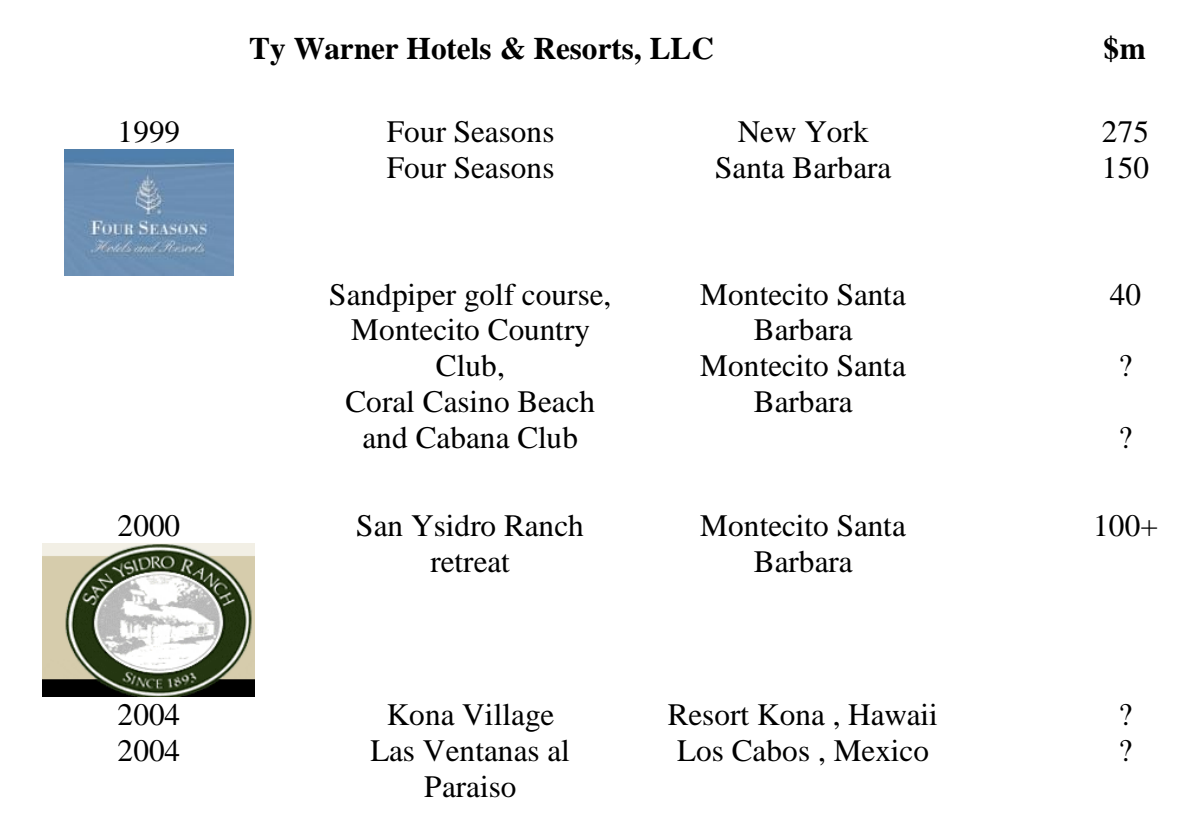

With the purchase of the Four Seasons Hotel, New York Warner bought one of his favourite hotels. It had been on the market for 18 months. This was followed by the creation of Ty Warner Hotels \& Resorts, LLC which is solely owned by Ty Warner.

As with the designing of Beanies Warner is a hands-on owner who is intimately involved in each and every aspect of his hotels and resorts.

At the 540-acre, 38 individually distinct cottages of the Montecito ranch and hotel Warner has handselected the oriental rugs, antiques and artwork, even arranging knickknacks on bookshelves, advising on colour schemes and where towel racks hang in the bathrooms. So far each cottage upgrade has cost $\$ 500,000$.

However, along with improvements came room rates increases.

You're not just renting a room when you come here, said Marc Appleton, hired by Mr. Warner to lead the architect and design team on the renovation.

You're renting the experience, the privacy, the romance, the seclusion, the history, all in your own little house.

\begin{tabular}{|c|c|c|}
\hline Cottages & Historic Rate Per night & Renovated 2004 Rate Per night \\
\hline Gardenia Cottage & $\$ 899$ & $\$ 1,495$ \\
\hline Jasmine Cottage & $\$ 599$ & $\$ 795$ \\
\hline JFK Cottage & $\$ 1,875$ per night & Still to be renovated \\
\hline
\end{tabular}

Warner's purpose was to acquire one-of-a-kind, irreplaceable luxury hotels and resorts throughout the world. He is not interested in merely owning such properties, but in evolving them into luxury icons by creating a dynamic vision for rejuvenation and enhancement.

In September 2004 it was announced that The Mankarios Partnership, a provider of asset management, hotel and resort management and technical services for independent hotels and resorts, had been engaged as the 
management company of the Kona Village Resort and as the Asset Manager of Las Ventanas al Paraiso by Ty Warner Hotels \& Resorts.

The Mankarios Partnership has clearly demonstrated its unique expertise and ability to help our company realize our vision in the luxury hospitality marketplace,

said Ty Warner, Chairman and CEO of Ty Warner Hotels \& Resorts.

To achieve and sustain excellence is an ongoing practice, not just an aspiration, and we have engaged the practitioners who clearly understand our particular definition of unparalleled excellence, which is both unique and specific to each of our properties.

By November 2004, The Mankarios Partnership were further engaged to direct and oversee the rejuvenation and enhancement of the luxury Hawaiian resort. Las Ventanas al Paraiso in Los Cabos, Mexico , which was acquired by Ty Warner Hotels \& Resorts.

\section{FOOTNOTES}

1: $\quad$ Ty has only granted 3 interviews to date;

- 1996 - People Magazine

- 1996 - Forbes Magazine

- 1999 - USA Today

2: Ty Warner was named in honour of a Twenties baseball star, the brilliant, if huggish, Ty Cobb of the Detroit Tigers, who famously once beat up a crippled heckler.

3: $\quad$ Dakin - originally established in 1955 closed down in 1995

4: $\quad$ Poem: Spot

See Spot sprint, see Spot run

You and Spot can have lots of fun

Watch out now, because he's not slow

Just stand back and watch him go!

5: limiting sales to niche retailers and curbing supplies to create pockets of scarcity (sometimes gaping pockets - one Easter he had to lease three 737's to fly emergency shipments from the factory in Korea),

6: $\quad$ Lengths people have gone to get Beanie Babies:

- $\quad$ former bank president and wife charged in Wisconsin with embezzling millions of dollars - a large amount of it on Beanies.

- $\quad$ Obsessive Californian woman stole credit cards to buy Beanies.

- $\quad$ people lined up to hand over firearms in a Guns for Beanie Babies promotion sponsored by the Kankakee III Police Department.

- $\quad$ For a while, the Customs Service, acting on a request from Ty limited travellers entering the country to one Beanie Baby per family. The limit was later raised to 30 .

Sunday Telegraph, 18 July 1999 releases.

In Japan, collectors have been known to wait in line overnight to purchase some of Ty Inc.'s exclusive new 
7: At least 25 million Americans - 66 percent of them women - hunt for antiques and 59 percent of collectors use the Internet, according to a study that national polling company A.C. Nielson conducted for Country Home magazine and eBay. Eighty-five percent of respondents said eBay has made collecting easier and more fun.

8: $\quad$ 'Teeny Beanies' with their Happy Meals in America, six weeks' supply of toys ran out in three days. Such was the frenzy, many customers just threw away the burgers and fries.

\section{APPENDIX 1 TIME LINE}

1986 Inc. Ty, Inc. was established in Oak Brook, Illinois . Ty Warner, who had previously worked for a toy plush manufacturer called Dakin, his first line of plush to be released where 4 Himalayan cats named Smokey, Ginger, Peaches and Angel.

1991 Ty launched a line called "Annual Collectible Bears." These made Ty quite successful and well known as a plush manufacturer. During this year Ty also began branching his company to England, Canada and Europe . Some older Ty products still say "Deutschland, Nuremberg" inside of their hang tags. This location has since been closed though.

1993 Seven years after Ty, Inc. was founded Ty releases his first Beanie Baby creations Brownie and Punchers in early 1993. During the later half of the year Ty released the Original Nine beanies, Legs the Frog, Squealer the Pig, Brownie the Bear ( later renamed to Cubbie the Bear), Flash the Dolphin, Splash the Whale, Patti the Platypus, Chocolate the Moose, Spot the Dog and Pinchers the Lobster at the New York Toy Fair.

1994 Beanie Babies are starting to become known as a collectable and not just a toy throughout the Chicago area. Since the introduction - of the Original Nine more than 3 dozen other Beanie Babies have been added to the collection. Ty sells Beanie Babies directly to small specialty gift shops, avoiding the loss of control and costs of selling through a wholesaler. Beanies sporting a new hang tag are now seen, this becomes known as the 2nd generation hang tag.

1995 Beanie Babies go nation wide! Stores outside of the Chicago area are now able to order Beanie Babies. This leads to the introduction of the $3 \mathrm{rd}$ generation hang tag. Ty only sells his plush to small collectables and gift stores. This will later prove to be a large part of why they are so successful selling.

1996 Just when some experts thought the beanie 'fad' would fade after the Christmas of 1995 sales grew tenfold! Stores had problems meeting demand and Ty had problems getting beanies to stores on time. Ty leases three airliners to rush a special shipment from overseas to the stores in time for Easter.

Ty launches website www.Ty.com This will become the only portal the outside has into the world of Ty. People will start to use the website to trade beanies with other collectors around the world. This is also the first time Ty shows some form of advertising for his company. Popularity of his product spread through the media and word of mouth.

With the development of the website beanie retirements are now officially announced on the site, prior to the website they were simply removed from the retailers ordering form and no longer made.

This year is also the release of the first exclusive beanie baby, Maple the Canadian bear is released in Canada where only Canadian retailers are able to order them. This leads to the introduction of the 4 th. generation hang tag.

Ty does his first interview with People Magazine and another later in the year with Forbes Magazine.

1997 Ty and McDonalds partner up to start the biggest Happy Meal promotion of all time. Miniature Beanie Babies called Teenie Beanies are given away with Happy Meals! McDonald's around the nation are flooded with fans in search of each Teenie Beanie.

This same year the first Sports Promo Beanie is announced. 10,000 Cubbie Bear beanies are given away to children at a Chicago Cubs game. Ty himself threw the first pitch at the game.

Ty U.K. and Ty Deutschland consolidated into Ty Europe.

Ty gives his employees a special bear, exclusive to them, called "1997 Employee Bear."

The 5th generation hang tag is also released. Also Britannia the first European exclusive bear is introduced. 
1998 A second McDonalds's Teenie Beanie promotion is done, this time they sell 250 million Teenie Beanies. Ty's sales exceed I Billion dollars now making him the most successful toy manufacture in the world.

Ty also gives his employees another exclusive beanie, each employee received 2 Billionaire Bear Beanie Babies. This same year he gave each Ty Representative a No.1 Bear exclusive to them.

Tylon developed - exclusive plush fabric on new line "Beanie Buddies".

Ty launches the first Beanie Baby for charity. Princess, royal purple bear with a rose is released to remember Princess Diana and to raise money for the Princess Di Foundation. Ty donates 10 million dollars from the proceeds of Princess beanie sales.

1999 Germany gets their first exclusive called Germania .

New tush tags released. These new high tech tags now sport holograms and a special ink to help crack down on counterfeiters.

Germany 's McDonald's along with USA McDonald's launch a promotion of Teenie Beanies.

Ty gives out another employee exclusive bear called Billionaire II.

Ty bought New York Cities tallest hotel, the New York City 's Four Seasons Hotel for \$275 million.

The BBOC, Beanie Babies Official Club is created.

Ty does an interview with USA Today.

Ty announces that he would be retiring all Beanie Babies at the end of the year. A bear named "The End" is released and adds to the excitement. At the end of the year Ty lets the collectors of the world decide the fate of Beanie Babies. He also collects a small fee from each person who voted and donates the money to charity.

Collectors all over agree that Ty should continue with the Beanie Baby line!

Beanie Babies introduced into Japanese Market.

2000 Ty introduces new lines, including Beanie Kids at the New York Toy.

A Germania Buddy is introduced,

Japan receives an exclusive called Sakura

USA receives an exclusive called USA Bear.

The 540-acre Montecito ranch and hotel purchased.

2001 Issy the charity bear released: now 63 different versions! One for each of the Four Seasons Hotels.

April Ty announces the People's Beanie competition!

Ty announces partnership with MBNA MasterCard to give away a free beanie when you apply for the card!

Ty introduces "Jingle Beanies", these are smaller versions of popular beanies, but they are bigger than Teenie Beanies. They are meant to be hung from the Christmas Tree, the following Jingles are released:

1997 Holiday Teddy

1998 Holiday Teddy

1999 Holiday Teddy

Halo

Loosy

Peace

Quackers

Rover

Twigs

September 13, 2001 Ty announced America the first in a series of charity bears to raise funds for those effected by the terrible terrorist events of September 11, 2001.

Ty Warner signed an America Bear and put it up for auction on Ebay.com where it sold for \$24, 000!

2002 In January Ty announces a Ty sponsors Beanie magazine called Mary Beth's Beanies \& More, this new magazine now contains no ads!

2004 July: the Kona Village Resort acquired

Sept.: The Mankarios Partnership, engaged as the management company of the Kona Village Resort and as the Asset Manager of Las Ventanas al Paraiso.

November: The Mankarios Partnership engaged to direct and oversee the rejuvenation and enhancement of the luxury Hawaiian resort and Las Ventanas al Paraiso in Los Cabos, Mexico. 


\section{Questions}

1. To what extent have the functional areas such as marketing, production and finance contributed to the success of the Beanie baby phenomenon.

2. With the use of tools of analysis critically assess Ty Incorporated's ability to maintain its strategic advantage.

\section{GUIDE}

Ty Inc

Ty Inc., the most successful and profitable company in the history of the U.S. toy

Industry, with over $\$ 1$ Billion in sales developed the Beanie Baby, a small inexpensive toy filled with polystyrene beads and small enough to fit into a child's hand was introduced in 1993 as part of a promotion with the McDonald's Burger Chain.

\section{Overview}

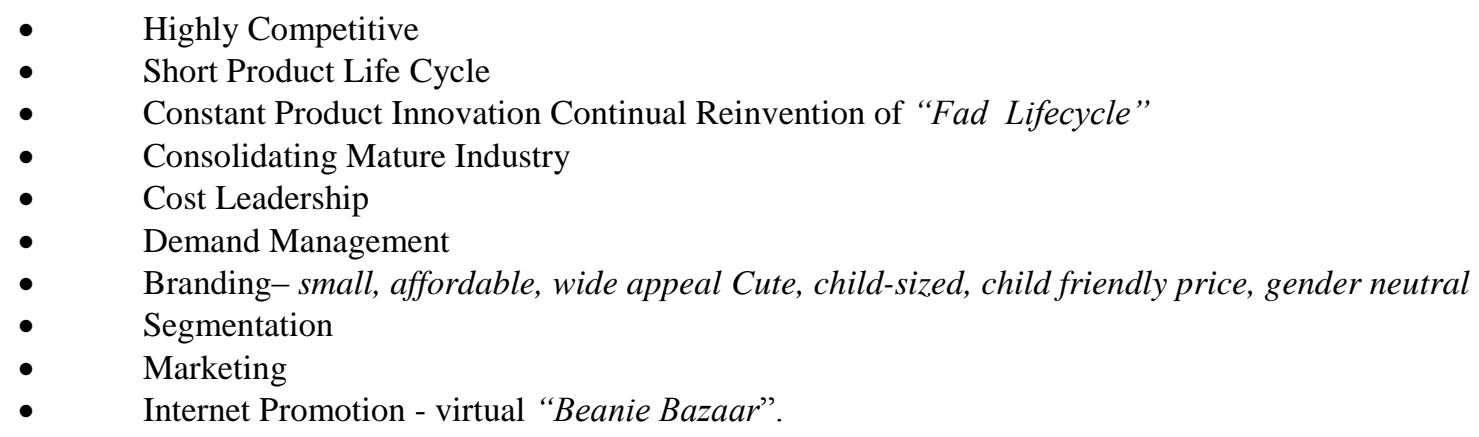

\section{H. Ty Warner}

Ty Warner is the sole owner of Ty Inc. He is an ex-toy salesman with deep industry knowledge. His initial philosophy was "to provide a back-to-basics toy that children could afford to buy with their pocket money".

\section{Objective}

- $\quad$ To become the leading manufacturer of plush toys throughout the world.

- Has managed to maintain the origins and "core ethos" of the company - concentrating on the child as the decision making unit.

\section{Competition}

- $\quad$ The marketing of stuffed toys is an aggressive market.

- $\quad$ Competitive marketing is predominantly backed by expensive advertising campaigns, costly R\&D and huge licensing deals.

- $\quad$ High Barriers to Entry - high volume, low price, high profitability.

- Patent Protection.

There are barriers to entry - high volume, low price and high profitability. Ty can reduce his price in response to competition. 


\section{Promotional Activity}

- $\quad$ Promotion through MacDonalds - Push Marketing

- $\quad$ More than 43,000 Beanie Baby sites are listed.

- $\quad$ Official site the most popular on the WEB with more than 2 billion visitors.

- $\quad$ The Beanie Bible attracts more than one million readers in the US and about 40,000 in UK.

\section{Product Strategy}

- $\quad$ Collectors item.

- $\quad$ Pull Marketing.

- $\quad$ Creation of demand - retirement of toys.

- $\quad$ Development of accessories.

- Unique "characterisation" of toys.

- $\quad$ Manipulates market for demand.

- "Club Culture".

- $\quad$ Marketable events - Charities, Events, Armed Forces, Nationality, etc.

The product has wide appeal. Not only is it a toy, but a collectors item for all ages and genders.

\section{Production Strategy}

- $\quad$ Production - Low Cost, Flexible, Predictable.

- $\quad$ Manufactured worldwide.

- $\quad$ Short launch times.

- $\quad R \& D$ to improve products.

- Utilisation of technology.

- Zero Waste - imperfections acceptable.

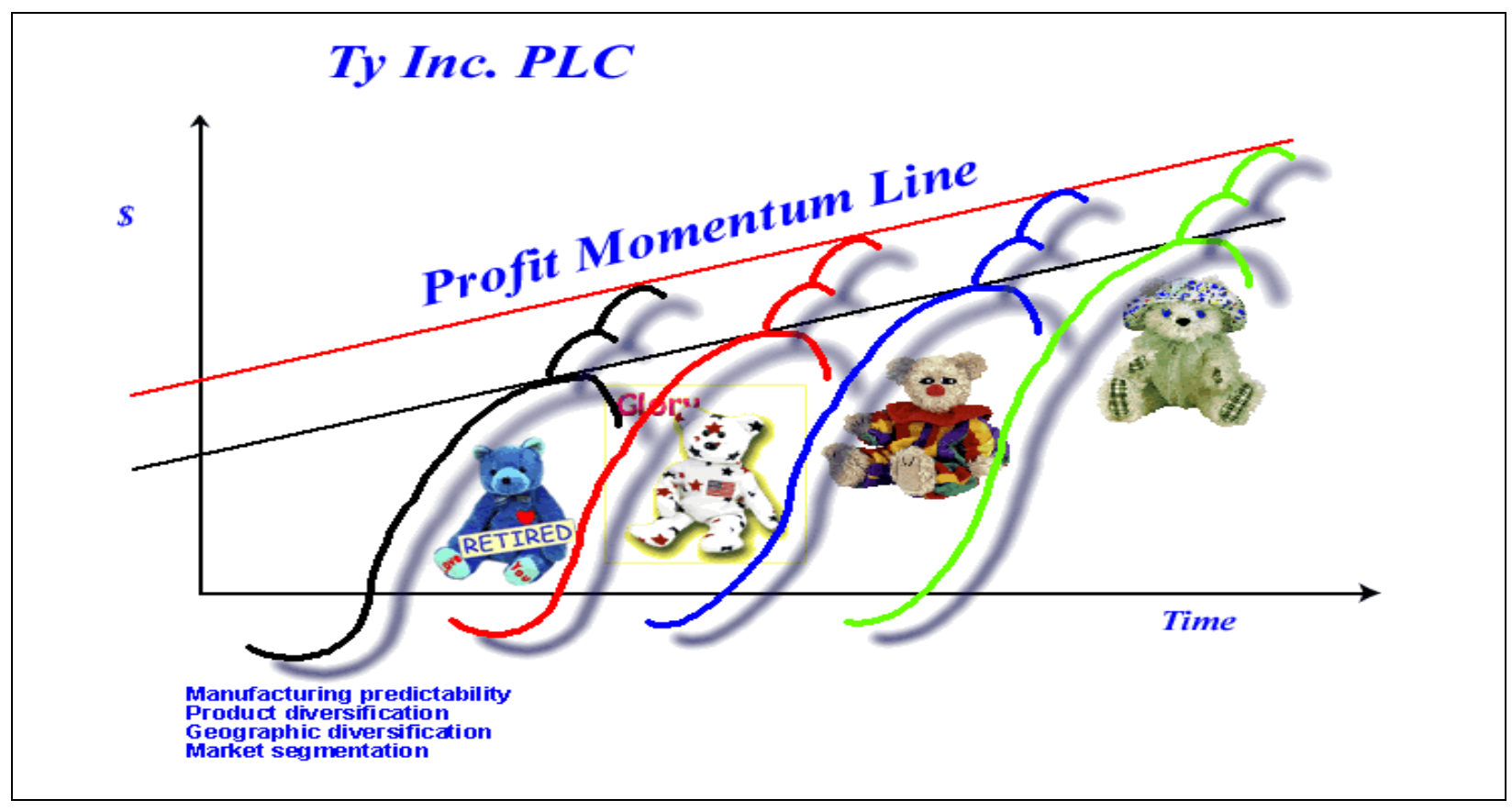


Imperfections were seen as an asset providing character and individuality to what is a mass produced toy.

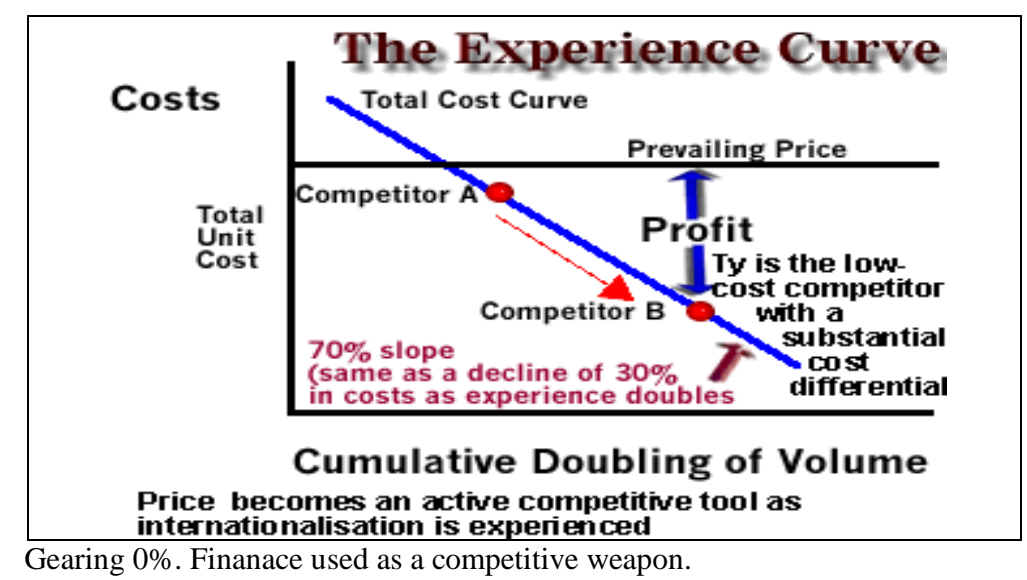

\section{Distribution}

- $\quad$ Sold well from the beginning, first signs of "Beanie Mania", Summer 1995.

- $\quad$ Ty have a low key marketing approach - limited distribution, direct to small retail outlets not majors or multiples

- $\quad$ Direct Control of Distribution Channels

- $\quad$ Transportation - small, light \& unbreakable, but in mass quantities.

- $\quad$ Sophisticated Supply Chain.

- $\quad$ Location of manufacturing lowers transportation and distribution costs.

Initial take-off when BB went from cult favourite to culture sensation, creating a product shortage which spurred demand this may have led to initial idea of restricting numbers and creating "elusive" quality.

\section{Marketing Strategy}

- Initially targeted at children - wider appeal.

- $\quad$ Average age of collector is 45 years.

- $\quad$ Continual additions to product range.

- Desirability and exclusivity.

- Extensive use of Web to promote product "club" ethos - global market

- $\quad$ No direct advertising costs.

- $\quad$ Child \& parent friendly prices.

Ty have created a variety of Beanie Baby collections - Beanie Babies, Beanie Buddies, Beanie Kids, etc. They remain the same product type, but recreated differently like little people instead of animals, bigger or smaller versions of the original Beanie Babies.

\section{Pricing}

- "Child friendly" pricing strategy.

- $\quad$ Beanies start at around $\$ 6$ (UK price $£ 4.99$ ),

- $\quad$ Once retired can fetch thousands of dollars from collectors. (US @ $£ 3,000$ for rare items, UK @ £200 limited edition Britannia Beanies). 
Common Global Pricing Strategy Beanie Baby

Key Success Factors

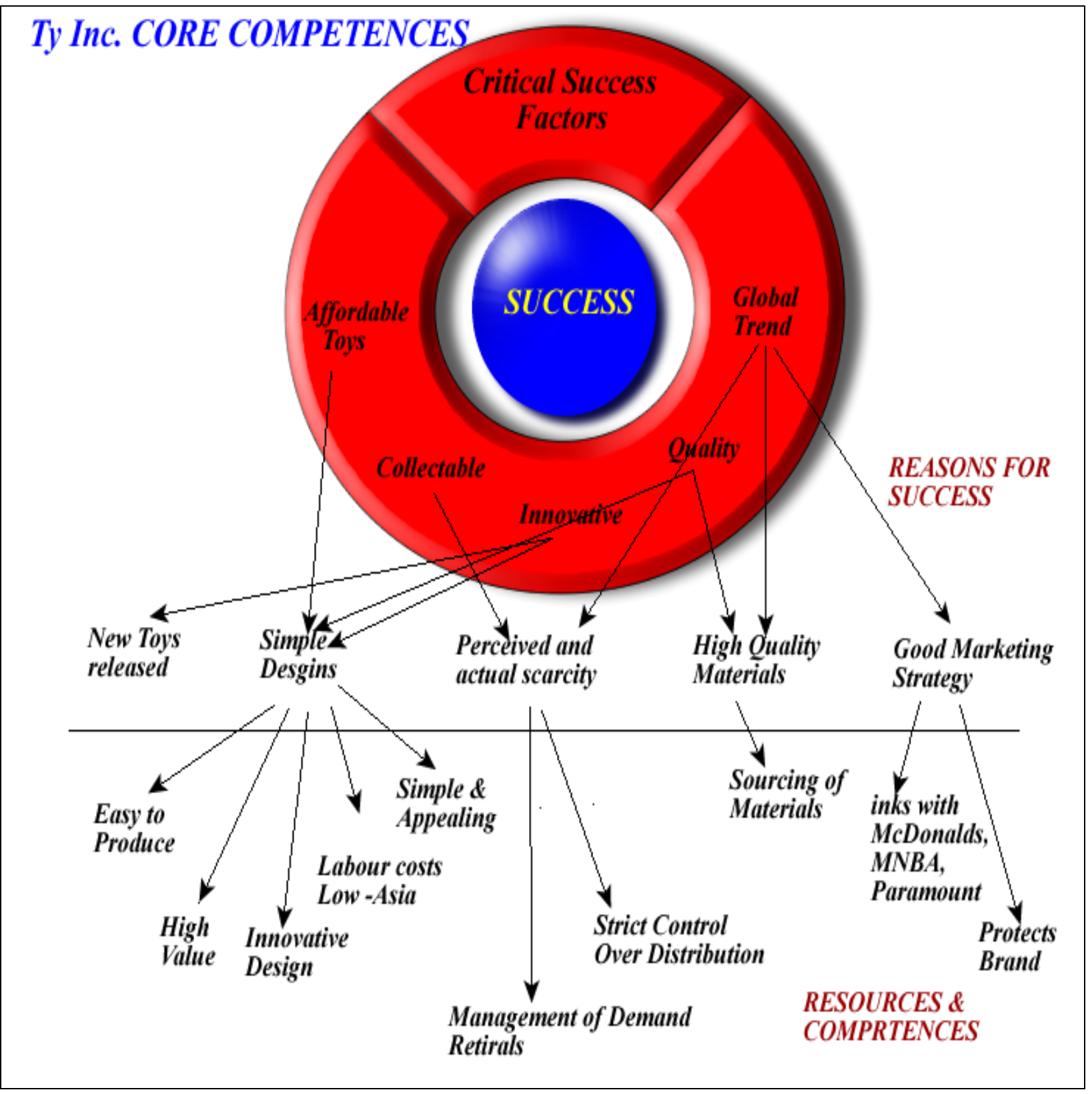

- $\quad$ Philosophy - home market developed on a global basis.

- $\quad$ Production in low cost countries.

- $\quad$ Key part of the Beanie phenomenon involves the "joy of the hunt" in tracking them down.

- Real value is created by clever development of "exclusive" and "elusive" qualities of what are just inexpensive soft toys, no real intrinsic value.

- $\quad$ Entrepreneurial balanced with professional management team. 


\section{Ty Inc. Value Chain}

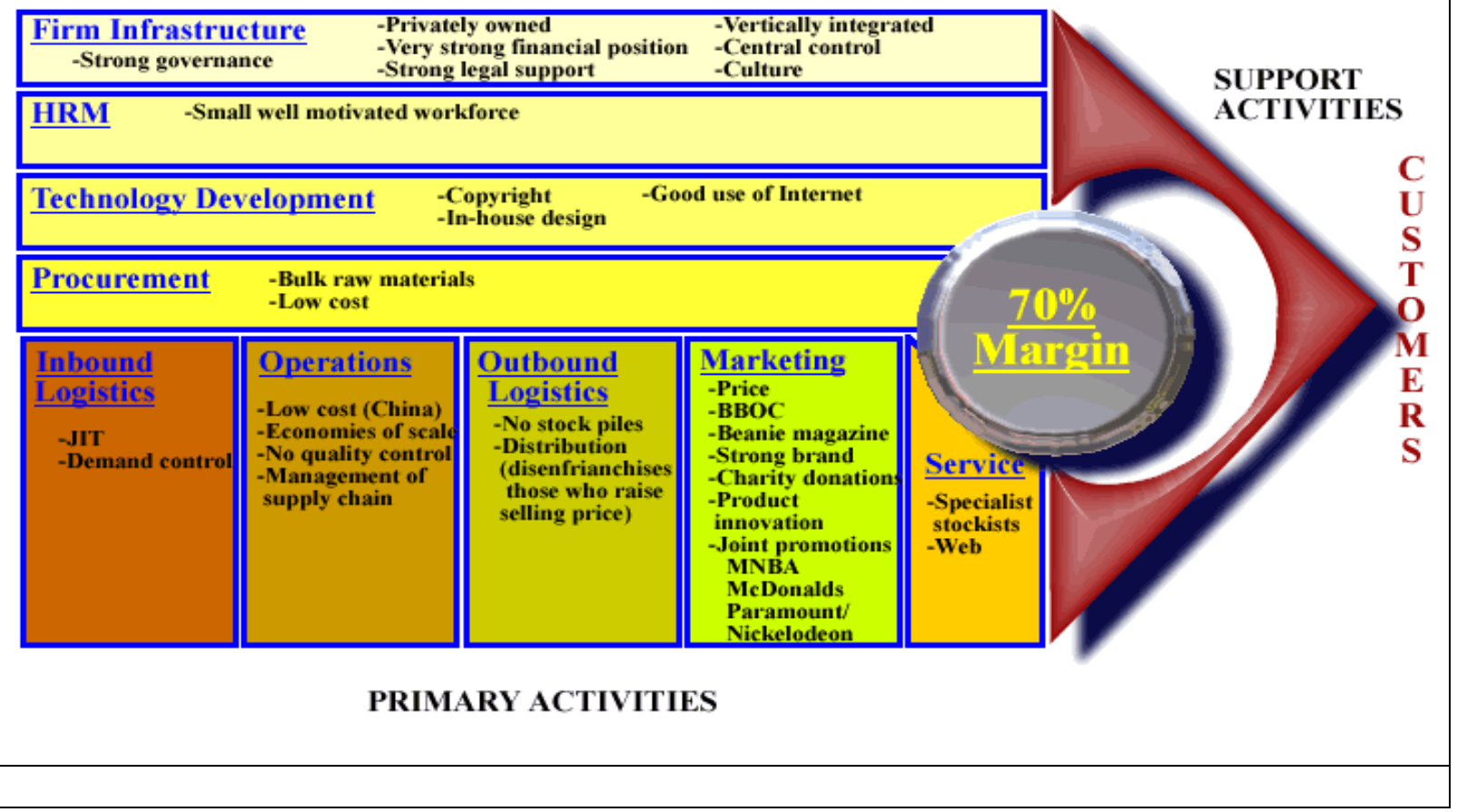

\section{Threats}

- $\quad$ Reliance on Ty Warner

- $\quad$ Single Product Company - phenomenal growth but equally phenomenal decline if tastes (demand) change. 
NOTES 